\title{
Procesy transformacji współczesnych miast na wybranych przykładach miast
}

\author{
Dorota Jopek
}

Uniwersytet Ekonomicznyw Krakowie, jopekd@uek.krakow.pl

\begin{abstract}
Streszczenie: Współczesne miasta doświadczają dynamicznych zmian przestrzennych związanych z czynnikami demograficznymi, społecznymi i gospodarczymi. W wyniku tych czynników mogą występować całkowicie skrajne wyzwania rozwojowe tych ośrodków miejskich. Część miast podlega bowiem procesom depopulacji związanym zarówno z ujemnymi trendami demograficznymi jak i wzrostem bezrobocia oraz brakiem ofert pracy dla ludzi młodych. Drugą część miast stanowią ośrodki dysponujące lepszym potencjałem rozwoju wywodzącym się najczęściej z ich historycznej roli w procesie rozwoju całego kraju realizowanych na różnych płaszczyznach. Ta różnorodność czynników rozwoju jest kreowana przez sprawne funkcjonowanie instytucji naukowych, kulturalnych oraz prywatnego sektora gospodarczego. Atrakcyjność tych miast wynika z większej i zróżnicowanej oferty na rynku pracy oraz lepszych warunków życia dla ich mieszkańców realizowanych między innymi poprzez dostępność wysokiej jakości przestrzeni publicznej.

W badaniach nad procesem transformacji miast, aspekty przestrzenne wydają się mieć mniejszą wagę w zestawieniu z aspektami gospodarczymi, demograficznymi czy społecznymi. Mimo, że niekwestionowana jest ich współzależność to jednak właśnie zmiany przestrzenne stanowią wynikową trzech pierwszych aspektów. Analiza dokumentów planistycznych i strategii rozwoju miast wykazuje że większość z nich jako główne cele wskazuje poprawę jakości życia mieszkańców oraz realizację zasad zrównoważonego rozwoju. W niniejszej pracy autorka podejmuje próbę badania procesów transformacji jakie zachodzą we współczesnych miastach.
\end{abstract}

Słowa kluczowe: miasto, globalizacja, rewitalizacja, depopulacja.

\section{Wprowadzenie}

Transformacja struktury przestrzennej współczesnych miast jest związana z procesami zachodzącymi w ekonomicznych, demograficznych, społecznych i przestrzennych aspektach ich rozwoju.

W wyniku oddziaływania różnej kompilacji tych czynników mogą występować całkowicie skrajne wyzwania rozwojowe tych ośrodków miejskich. Część miast podlega bowiem procesom depopulacji związanym zarówno z ujemnymi trendami demograficznymi jak i wzrostem bezrobocia oraz brakiem ofert pracy dla ludzi młodych. Zmiany przestrzenne związane z depopulacją miast dotyczą najczęściej degradacji przestrzennej obszarów miejskich zamieszkiwanych przez najbiedniejsze grupy społeczne lub obszarów opuszczonych w wyniku migracji co z kolei ma wpływ na czynniki społeczne związane z powstawaniem stref wykluczonych. Procesy te stanowią duże wyzwaniem dla władz miast w procesach kształtowania polityki miasta, wprowadzania nowych form planowania działań i zarządzania 
lokalnego. W tym kontekście bardzo istotny jest również temat efektów działań naprawczych czyli zmierzających do odwrócenia negatywnych trendów demograficznych. W niektórych miastach bowiem priorytetem dla działań władz miejskich jest pozyskiwanie nowych inwestycji, które pozwolą na poprawę sytuacji na rynku pracy oraz staną się ogniwem w budowaniu (czasem odbudowywaniu) atrakcyjności inwestycyjnej danego miasta.

Druga część miast podlegających transformacjom struktury przestrzennej stanowią ośrodki dysponujące lepszym potencjałem rozwoju wywodzącym się najczęściej z ich historycznej roli w procesie rozwoju całego kraju realizowanych na różnych płaszczyznach. Ta różnorodność czynników rozwoju jest kreowana przez sprawne funkcjonowanie instytucji naukowych, kulturalnych oraz prywatnego sektora gospodarczego. Atrakcyjność tych miast wynika z większej i zróżnicowanej oferty na rynku pracy oraz lepszych warunków życia dla ich mieszkańców realizowanych między innymi poprzez dostępność wysokiej jakości przestrzeni publicznej. Lepsze warunki życia dotyczą bardziej sfery społecznej, gospodarczej i przestrzennej bowiem wraz ze wzrostem liczby mieszkańców jak i innych użytkowników miast rosną problemy ekologiczne związane głównie z zanieczyszczeniem powietrza czy zabudowywaniem korytarzy ekologicznych miasta. Wyzwaniami z którymi miasta te muszą się zmierzyć to duża presja inwestycyjna szczególnie w sektorze rynku mieszkaniowego, handlowo-usługowego, komercjalizacja przestrzeni oraz duże obciążenie systemu komunikacyjnego miasta. Atrakcyjność inwestycyjna miast wiąże się najczęściej ze wzrostem wartości nieruchomości co z kolei wywołuje procesy gentryfikacji i suburbanizacji czyli nadmiernej urbanizacji peryferyjnych obszarów miast i terenów podmiejskich. Kryzys miast powinien być więc rozpatrywany $\mathrm{w}$ różnych aspektach ale również $\mathrm{w}$ odniesieniu do indywidualnych uwarunkowań poszczególnych miast czy regionów. Istotna jest również analiza działań podejmowanych w celu odnowy struktury gospodarczej, społecznej i przestrzennej miast jako zestaw dobrych praktyk mogących inicjować zmiany również w innych ośrodkach.

\section{Przemiany przestrzeni miasta}

Przemiany procesów urbanizacyjnych wynikają z opisanej przez L. Klassena koncepcji cyklu miejskiego. Obejmuje on cztery główne fazy: urbanizacji, suburbanizacji, dezurbanizacji i reurbanizacji [2]. Skutkiem urbanizacji jest gwałtowny wzrost liczby ludności mieszkającej w miastach, szczególnie w jego częściach centralnych. W fazie suburbanizacji miasta rozrastają się przestrzennie tworząc coraz szerszą strefę podmiejską zatracając granicę pomiędzy obszarami miejskimi i wiejskimi.

Krańcową formą suburbanizacji jest dezurbanizacja - rozumiana jako zanik miasta jako ograniczonej struktury przestrzennej na rzecz niczym nieograniczonych wielkich regionów funkcjonalnych [4]. Charakterystyczną cechą dezurbanizacji jest spadek znaczenia śródmieścia i spadek liczby mieszkańców nie tylko w dzielnicach centralnych ale również w dotychczasowych dzielnicach podmiejskich. Wiąże się to często albo z utratą funkcji handlowej centrum miasta na rzecz obszarów peryferyjnych gdzie lokalizowane są wielkie centra handlowe lub też ze wzrostem przestrzennym strefy podmiejskiej zarówno w zakresie funkcji mieszkaniowych jak i przemysłowych. Reurbanizacja jest fazą związaną z podejmowaniem prób mających przywrócić wagę i znaczenie dzielnicom śródmiejskim poprzez realizację programów rewitalizacyjnych co z kolei wpływa na relatywnie szybszy wzrost liczby ludności w śródmieściach niż na peryferiach miasta.

Wymienionym procesom urbanizacyjnym towarzyszą przemiany miasta związane z procesami globalizacji, rewitalizacyjnymi, wyludniania się struktur miasta czy też budowania rozwoju miasta w oparciu o idee zrównoważonego rozwoju. W niektórych przypadkach 
transformacje te są elementem lub skutkiem procesów urbanizacyjnych jak na przykład globalizacja może stanowić specyficzne ujęcie urbanizacji, depopulacja miast, jest między innymi wynikiem suburbanizacji, rewitalizacja - dezurbanizacji a idea zrównoważonego rozwoju jest ściśle związana z reurbanizacją.

\subsection{Globalizacja}

Transformacje przestrzeni miasta związane z procesami urbanizacji odnoszą się do wszystkich ośrodków, w tym również dla miast globalnych lub aspirujących do tego miana. Proces globalizacji jest obecnie uważany za główną siłę dynamizującą światową ekonomię. Jednocześnie globalizacja stanowi kombinację szeregu rozmaitych procesów, w tym - urbanizacji. Jej skutki mają zaś znaczenie zarówno dla przestrzeni, gospodarki, ale przede wszystkim - dla społeczeństwa [4]. Efektem globalizacji jest transformacja struktury przestrzennej miast oraz tworzenie nowych relacji pomiędzy węzłami globalnej sieci powiązań i oddziaływań.

Saskia Sassen zdefiniowała miasto jako arenę szczególnych przemian społecznych w których konkretyzują się procesy globalizacji. Zdaniem jej, globalizacja w znacznej mierze rozgrywa się w miastach i dzięki miastom oraz, że nie są to już po prostu miasta, lecz miasta globalne [5]. Miasto globalne to miasto w sieci miast globalnych tworzących system centralnych ośrodków decyzyjnych w strukturze gospodarki światowej, szczególnie w zakresie sektora finansowego i bankowego, oraz produkcji informacji i innowacji.

Globalizacja ujednolica normy działania i produkcji, które sprawiają, że nie tylko możliwa, ale też bardzo ułatwiona jest współpraca pomiędzy ośrodkami miejskimi. W aspektach przestrzennych zjawisko globalizacji jest związane z unifikacją wzorców kształtowania przestrzeni publicznych jak i obiektów budowlanych. Ujednolicenie standardów powoduje, że miasta stają się podobne, szczególnie w zakresie przestrzeni biznesowych (dzielnice biurowe), transportowych (dworce, lotniska) i konsumpcyjnych (centra handlowe).

Negatywnym efektem takiej unifikacji jest zatracenie unikalnych wartości kulturowych charakterystycznych dla danego miejsca $\mathrm{w}$ imię podporządkowania się globalnej tendencji zapożyczania czy wręcz kopiowania wzorców innych kultur. Kopiowanie wzorców kulturowych, a w zasadzie najczęściej jedynie jej fragmentów, pozbawionych swych powiązań źródłowych prowadzi do tworzenia pozbawionej treści imitacji. Następuje więc proces upraszczania znaczenia a przez co zubożenie lokalnych wzorców będących odzwierciedleniem długoletnich tradycji miejsca. Wydaje się to szczególnie niebezpiecznym zjawiskiem w kontekście budowania tożsamości narodowej nowych pokoleń.

Transformacja przestrzeni miast globalnych jest najczęściej zauważalna w realizacjach prestiżowych dzielnic biznesowych czego przykładem mogą być dzielnice biurowe Canary Wharf w Londynie czy La Defense w Paryżu. Obecność wielkich globalnych firm i wielkich pieniędzy jest również zauważalna w krajobrazie miasta dzięki ikonicznym, najczęściej wysokościowym, budynkom biurowym. Budynki te, realizowane często w centralnych rejonach miast, dzięki swej śmiałej formie architektonicznej sygnowanej przez najbardziej znanych twórców, wchodzą do kanonu atrakcji turystycznych. Jednym z nich jest zaprojektowany przez Renzo Piano londyński wieżowiec o nazwie Shard, który w chwili ukończenia w 2012 roku był najwyższym budynkiem w Europie. Wieżowiec, który został zrealizowany w miejscu wyburzonych budynków Southwark Towers nieopodal London Bridge stał się jedną z atrakcji turystycznych Londynu.

Na tle tworzenia się nowych powiązań sieci jednostek globalnych, w szczególny sposób rozwinął się sektor turystyczny oparty na konkurencji pomiędzy miastami. Dotyczy to 
działań zarówno w zakresie pozyskania kapitału w postaci nowych inwestycji, jak również wydarzeń sportowych i kulturalnych, które obok korzyści finansowych mają charakter prestiżowy. Wydarzenia o charakterze prestiżowym bowiem mają tworzyć nowe możliwości rozwoju miasta w budowaniu lub najczęściej wzmocnieniu jego marki na arenie międzynarodowej.

W wymiarze przestrzennym ma to duże odzwierciedlenie w transformacji przestrzeni miasta dzięki realizacji dużych inwestycji publicznych do których należą m.in. hale widowisko - sportowe czy centra kongresowe.

Z uwagi na to, że głównym zarzutem kierowanym w kierunku globalizacji jest zatarcie się różnic kulturowych poszczególnych ośrodków miejskich, większe znaczenie zyskują działania, które za podstawę rozwoju wskazują potencjał lokalny wzmacniający indywidualny charakter poszczególnych ośrodków. W tym kontekście używane jest pojęcie glokalizacji, której celem jest takie dostosowanie globalnych strategii rozwojowych, by przyczynity się do rozwoju lokalnych rynków $i$ współdziałały z lokalnymi tradycjami. [6].

\subsection{Rewitalizacja}

Odzyskiwanie terenów miejskich jest związane z rewitalizacją obszarów które na skutek przemian gospodarczych i społecznych utraciły swą pierwotną funkcję co dotyczy zarówno dawnych terenów przemysłowych, portowych, kolejowych czy wojskowych. Transformacje przestrzenne współczesnych miast dotyczą również ich śródmieść, które w konsekwencji zjawisk cyklu miejskiego Klassena utraciły swoją rangę społeczno - gospodarczą.

Procesy przekształceń niewykorzystanych, często rozległych terenów zabudowy poprzemysłowej, powojskowej, terenów poportowych, pokolejowych, itp.,są typowym zjawiskiem zachodzącym we współczesnych miastach światowych. Tereny te są najczęściej zlokalizowane $\mathrm{w}$ atrakcyjnych częściach miast, przez co ich potencjał rozwojowy jest bardzo duży, nie tylko z uwagi na atrakcyjną lokalizację ale również na tradycje miejsca. Tereny te są często przekształcane w przestrzenie publiczne - najczęściej parki. Przykładem może być tutaj Brooklyn Bridge Park w Nowym Jorku zrealizowany na terenach poportowych, które dzięki swej lokalizacji i pięknej panoramie Dolnego Manhattanu były również znakomitym terenem inwestycyjnym. Parkami zrealizowanymi na terenach pokolejowych jest m.in. park na torach High Line w Nowym Jorku i francuski Promenade Plantee - park na miejscu linii kolejowej w Paryżu.

Forma i funkcja zagospodarowania terenów zdegradowanych jest zależna od lokalnych uwarunkowań każdego z nich i woli właściciela. W przypadku gdy na rewitalizowanych terenach znajdują się istniejące budynki są one czasem adoptowane na obiekty użyteczności publicznej lub obiekty komercyjne połączone często z przestrzenią ogólnodostępną. Przykładem pierwszego rozwiązania może być Muzeum Armii Krajowej w Krakowie zlokalizowane na terenach powojskowych, natomiast przykładem kompleksu komercyjnego zrealizowanego na terenach pofabrycznych jest Manufaktura w Łodzi. W ramach tego założenia teren pomiędzy budynkami zaprojektowano jako przestrzeń publiczną a program funkcji komercyjnych został rozszerzony o funkcje kulturowym m.in. o muzea, teatr i kino.

W procesach rewitalizacyjnych bardzo istotne jest realizowanie ich na podstawie planów nie tylko w skali mikro, dotyczących danego obszaru projektowego, ale również w skali makro czyli w sieci powiązań w skali dzielnicy czy w planach wyznaczających politykę rozwoju całego miasta. Zagospodarowanie tych obszarów bowiem, przede wszystkim z uwagi na lokalizację i dużą dostępność terenów, może ożywić istniejącą strukturę przestrzenną i funkcjonalną miast i przynieść korzyści zarówno gospodarcze, przestrzenne jak i społeczne. 
Rewitalizacja dzielnic śródmiejskich jest również bardzo istotnym zagadnieniem, którą Zbigniew Zuziak definiuje jako zmiany strukturalne polegające na wzmacnianiu aktywności i atrakcyjności jego przestrzeni wskutek skoordynowanej strategii sektorów publicznego prywatnego [7].

Przykładem miasta, które realizuje szeroko zakrojony program rewitalizacji, w dużej mierze obejmujący cześć śródmiejską miasta, jest Łódź. Łódź jest miastem, którego wyjątkowa historia i nienaruszona w czasie II wojny światowej tkanka urbanistyczna tworzy duży potencjał rozwoju. Jednak miasto to od wielu lat zmaga się z problemem depopulacji i degradacji przestrzennej miasta. Według danych statystycznych regres demograficzny Łodzi rozpoczął się w 1989 roku związany i był głównie ze wzrostem bezrobocia w wyniku niekorzystnych przemian gospodarczych miasta w okresie transformacji ustrojowej. Niski poziom jakości życia mieszkańców w naturalny sposób znalazł swe odzwierciedlenie w niskiej jakości przestrzeni publicznej oraz pogarszającym stanie technicznym zabudowy i infrastruktury miejskiej.

Działania podjęte przez władze samorządowe są związane przede wszystkim z poprawą sytuacji gospodarczej i sytuacji na rynku pracy. Ich celem było również przywrócenie istotnej rangi miasta w skali kraju poprzez rozwój funkcji metropolitalnych a w ścisłym związku z tymi działaniami była odbudowa kapitału społecznego miasta. Przemiany przestrzenne ukierunkowane zostały zarówno w stronę poprawy jakości przestrzeni miejskiej, wydobycia wyjątkowego w skali europejskiej potencjału poprzemysłowej przestrzeni Łodzi oraz wprowadzenia zasad polityki rozwoju przestrzennego miasta.

Do działań mających największy wpływ na przemiany przestrzenne miasta należały podejmowane przez władze miejskie programy rewitalizacji. Zrealizowano kilka programów rewitalizacji, jeden z nich „Uproszczony lokalny program rewitalizacji wybranych terenów śródmiejskich oraz pofabrycznych Łodzi na lata 2004-2013”, przyjęty w 2004 roku, obejmował tak zwaną Strefę Wielkomiejską czyli duży fragment centrum miasta w granicach kolei obwodowej. Innymi podjętymi programami rewitalizacyjnymi był projekt „Kwartał Śródmiejski” realizowany w latach 2007-2013, „Uproszczony lokalny program rewitalizacji wybranych terenów śródmiejskich oraz pofabrycznych Łodzi na lata 2004-2013” (m.in. rewitalizacja osiedla patronackiego Księży Młyn, budowa Nowego Centrum Łodzi wraz $\mathrm{z}$ budową nowego centrum komunikacyjnego). W kontekście rewitalizacji śródmieścia i przywracania mu dawnego prestiżu na uwagę zasługuje również, zawierający elementy rewitalizacji, program remontowy «Mia100 Kamienic», który od 2011 r. objął ok. 170 miejskich budynków a który stopniowo został przekształcony w program „Mia100 kwartałów”. Kontynuacją wszystkich wspomnianych działań jest aktualizacja LPR uchwalona jako Lokalny Program Rewitalizacji Łodzi 2020+. Realizowane programy rewitalizacji Łodzi, zarówno w obszarze śródmieścia jak i terenów poprzemysłowych, miały na celu nie tylko utrzymanie dziedzictwa kulturowego i tożsamości miasta ale przede wszystkim poprawę wizerunku miasta. Kształtowanie pozytywnego wizerunku jest nie tylko istotne z punktu widzenia zachęty dla potencjalnych nowych użytkowników i inwestorów ale również, co jest znacznie trudniejsze, odbudowanie identyfikacji i poczucia tożsamości mieszkańców z miastem. W Łodzi stanowi to szczególnie ważny element, bowiem według wyników badań TNS OBOP, wykonanych na zlecenie Urzędu Miasta Łodzi w 2010 roku1, aż 67\% respondentów, w dużej części łodzian, odpowiedziało, że nie widzi nic szczególnego, co wyróżniałoby to miasto spośród innych.

Obszary zdegradowane, nie tylko pod względem architektoniczno - urbanistycznym ale również, a może przede wszystkim, społecznym są poważnym problemem w procesie zmian tego negatywnego wizerunku miast. Waga czynników społecznych jest jednym

1 Badanie wykonane na potrzeby opracowania „Strategii zarządzania marką Łódź na lata 2010-2016”. 
z najważniejszych elementów procesów rewitalizacyjnych. Trzeba jednak pamiętać, ze sama przebudowa czy poprawa walorów estetycznych jest jedynie kwestią finansową natomiast zmiana społecznych relacji oraz odbudowa poczucia tożsamości i identyfikacji mieszkańców $\mathrm{z}$ ich miastem jest kwestią znacznie trudniejszą i złożoną [3].

\subsection{Depopulacja}

Problemy związane z sytuacją demograficzną współczesnych miast dotyczą dwóch przeciwległych biegunów tego zagadnienia. Podczas gdy jedna grupa miast zmaga się z problemem ciągłego wzrostu swojej populacji, druga grupa obejmuje miasta gdzie spadek liczby ludności powoduje ich degradację zarówno w aspektach gospodarczych, społecznych jak i przestrzennych. Zarówno wzrost jak i spadek populacji stanowi duże wyzwanie dla władz miasta podczas formułowania planów rozwoju jak i dostarczeniu narzędzi pozwalających kontrolować skutki tych zjawisk na poziomie zapewnianiającym prawidłowe funkcjonowanie całego miasta. Do najważniejszych wyzwań związanych z procesami wzrostu ludności należą problemy mieszkaniowe, a przede wszystkim dostępność mieszkań zarówno socjalnych jak i lokali dla osób słabiej zarabiających oraz potrzeby rozwoju i modernizacji istniejącej infrastruktury technicznej i społecznej. Obok tych problemów, dużym wyzwaniem są pogłębiające różnice społeczne w aspektach kulturowych, ekonomicznych i rasowych. Największy wzrost ludności występuje w dużych miastach do których napływ ludzi jest związany z poszukiwaniem pracy i lepszych perspektyw kariery zawodowej. Inną grupę stanowią też migranci z krajów objętych działaniami wojennymi i represjami politycznymi i religijnymi.

Niezwykle złożonych problemów doświadczają miasta o dużym ubytku liczby mieszkańców nazywane miastami wyludniającymi się albo miastami kurczącymi (od angielskiego określenia 'shrinking cities'). Najwyższy poziom spadku liczby mieszkańców występuje w przypadku miast, których gospodarka związana była związana z funkcjonowaniem dużych zakładów przemysłowych lub gdy w mniejszych ośrodkach miejskich zakład taki stanowił najważniejszy ośrodek zatrudnienia dla liczby ludności. Głównymi czynnikami wpływającym na depopulację miast są działania związane z przekształceniami przedsiębiorstw, słabe możliwości rozwoju zawodowego, a w związku z tym duży odsetek migracji przy jednoczesnym niskim odsetku napływu nowych mieszkańców. Procesom tym często towarzyszy spadek liczby urodzeń związany ze słabą sytuacją materialną mieszkańców oraz dużym odsetkiem migracji ludzi młodych. Procesy te dotyczą zarówno małych miast jak i dużych miast - w przypadku Polski - wojewódzkich i według prognoz demograficznych do roku 2050, niemal wszystkie z nich odnotują spadek liczby mieszkańców [3].

Badając transformację i uwarunkowania procesów wyludniania się miast najbardziej istotnymi wydają się aspekty gospodarcze, demograficzne i społeczne. Aspekty przestrzenne jednak, chociaż wydają się mieć mniejszą wagę, stanowią wynikową i ścisłą współzależność z pozostałymi aspektami. Niekorzystne zmiany przestrzenne zachodzą bowiem najczęściej w wyniku wyludniania się miast i zubożenia ludności związanego ze spadkiem koniunktury gospodarczej czy wzrostem bezrobocia. Zmiany przestrzenne związane z procesami kurczenia się miast dotyczą najczęściej degradacji przestrzennej obszarów miejskich zamieszkiwanych przez najbiedniejsze grupy społeczne.

Do najczęściej zauważalnych negatywnych zmian w przestrzeni miejskiej powstałych w wyniku procesu kurczenia się miast należy wymienić:

- wzrost liczby pustostanów oraz terenów zdegradowanych czyli nieruchomości których stan techniczny nie pozwala na dalsze użytkowanie a z kolei brak na popytu rynkowego i chętnych użytkowników wpływa na niepodejmowanie prac remontowych, 
- występowanie zdegradowanych terenów, które pierwotnie były obszarami przemysłowymi, w różnym stopniu zanieczyszczonymi, które straciły swoich użytkowników (tak zwane brownfields),

- perforacja struktur przestrzennych - likwidacja, wyburzanie budynków a także całych zespołów zabudowy o niskim standardzie i jakości,

- postępujące zmniejszanie gęstości zaludnienia, uznane za negatywny czynnik na terenach śródmiejskich gdzie wskazana jest zwarta i czytelna tkanka urbanistyczna

- niska jakość przestrzeni publicznych i utrata znaczenia dzielnic śródmiejskich [3].

Tabela 1. Ludność ogółem (w osobach) stan i prognoza 2014-2050

\begin{tabular}{lccccc}
\hline Miasta & 2015 & 2020 & 2030 & 2040 & 2050 \\
\hline Białystok & 295003 & 293529 & 286654 & 274791 & 261430 \\
\hline Bydgoszcz & 355104 & 343750 & 318561 & 289980 & 262370 \\
\hline Gdańsk & 460664 & 457819 & 447260 & 431650 & 418892 \\
\hline Gorzów W. & 123728 & 121703 & 115967 & 108578 & 100977 \\
\hline Katowice & 299592 & 287334 & 261050 & 233446 & 208112 \\
\hline Kielce & 197266 & 190320 & 174327 & 155982 & 137871 \\
\hline Kraków & 759419 & 759220 & 749307 & 728035 & 710464 \\
\hline Lublin & 340917 & 333625 & 314936 & 290598 & 265480 \\
\hline Lódź & 699093 & 668406 & 606824 & 542732 & 484845 \\
\hline Olsztyn & 173999 & 172204 & 166857 & 158078 & 148753 \\
\hline Opole & 118970 & 115737 & 108087 & 99165 & 90600 \\
\hline Poznań & 541896 & 526063 & 488226 & 443721 & 402076 \\
\hline Rzeszów & 184685 & 187928 & 190771 & 189103 & 186878 \\
\hline Szczecin & 405584 & 398444 & 381668 & 360601 & 340074 \\
\hline Toruń & 201747 & 197213 & 186230 & 172223 & 157949 \\
\hline Warszawa & 1732470 & 1748046 & 1755502 & $2 \mathrm{E}+06$ & 1768418 \\
\hline Wrocław & 630264 & 625538 & 611359 & 591353 & 577658 \\
\hline Zielona G. & 118253 & 117456 & 114447 & 110273 & 106474 \\
\hline Zó & & & & & 4
\end{tabular}

Źródło: oprac. własne na podstawie: Uwarunkowania i konsekwencje procesu kurczenia się miast, A. Harańczyk (red.), Wyd. CeDeWu, sp. z .o.o., Warszawa 2015.

Transformacja przestrzeni miejskiej jaką można zaobserwować w miastach wyludniających się ma nie tylko negatywny wymiar. Do skutków tego procesu należy bowiem zaliczyć podejmowane i realizowane działania naprawcze zmierzające do odwrócenia negatywnych trendów demograficznych czyli rewitalizacja obszarów miejskich. Wspomniane prognozy demograficzne pokazują, że tak nie ma dużego miasta (z wyjątkiem Warszawy), które może ignorować trendy demograficzne (tabela. nr. 1)². W związku z tym niemal wszystkie miasta w nowo formułowanych strategiach rozwoju wskazują nie tylko rozwój gospodarczy ale również szeroko pojęte działania mające na celu podniesienie jakości życia w mieście

2 Dane pochodzą z projektu badawczego p.t Uwarunkowania i konsekwencje procesu kurczenia się miast zrealizowanego w 2015 roku w ramach badań statutowych Katedry Gospodarki Regionalnej Uniwersytetu Ekonomicznego w Krakowie. 
realizowane m.in. poprzez poprawę jakości i dostępności przestrzeni publicznych o wysokim standardzie.

Priorytetem dla działań władz miejskich stało się więc pozyskiwanie nowych inwestycji, które pozwolą na poprawę sytuacji na rynku pracy oraz będą ogniwem w budowaniu (czasem odbudowywaniu) atrakcyjności inwestycyjnej danego miasta. Pozyskiwanie inwestorów odbywa się często za pomocą zachęt inwestycyjnych w postaci ulg podatkowych czy preferencyjnych warunków pozyskiwania terenów inwestycyjnych. Wiąże się to również z uwalnianiem atrakcyjnych lokalizacji pod planowane inwestycje. Z tym mogą wiązać się w niektórych przypadkach, niekorzystne skutki przestrzenne tej działalności, szczególnie gdy bezwarunkowa chęć pozyskania inwestorów skutkuje podporządkowaniu się przez władze miejskie warunkom stawianym przez nich w zakresie zarówno funkcji jak i formy projektowanej zabudowy. Do innych negatywnych skutków w tym zakresie można zaliczyć realizowanie inwestycji na terenach o szczególnych walorach przyrodniczych i kulturowych, które nie są objęte dokumentami planistycznymi regulującymi warunki ich zabudowy i zagospodarowania. Niekorzystne przemiany przestrzenne zachodzą również w centralnych dzielnicach miast poprzez podyktowane tylko szybkim zyskiem zastępowanie istniejącej tkanki miejskiej nową zabudową.

Do najczęściej pozytywnych zmian należy zaliczyć:

- poprawę jakości zagospodarowania i estetyki dzielnic centralnych miasta mających na celu podniesienie atrakcyjności tych terenów dla potencjalnych inwestorów oraz obecnych i nowych mieszkańców, tworzenie wysokiej jakości przestrzeni publicznych integrujących lokalną społeczność,

- realizacja nowych inwestycji o znaczeniu kulturowym (np. muzea)

- tworzenie lub rozwój stref ekonomicznych dających dogodne zaplecze dla działań przedsiębiorców,

- rewitalizację obszarów kryzysowych wykazujących duże natężenie problemów gospodarczych, społecznych i przestrzennych będący skutkiem najczęściej wysokimi wskaźnikami stopy bezrobocia mieszkańców danego obszaru czy też niskimi walorami architektoniczno-urbanistycznymi,

- rewitalizację obszarów zdegradowanych: poprzemysłowych, powojskowych, pokolejowych, posiadających duży potencjał rozwoju najczęściej dzięki atrakcyjnej lokalizacji jak również interesujących - unikalnych w skali miasta walorach przestrzennych.

\subsection{Zrównoważony rozwój}

Idea zrównoważonego rozwoju miast to część strategii rozwoju większości współczesnych miast światowych, zarówno tych globalnych (np. Nowy Jork, Strategia PlaNYC2030) jak i tych mniejszych. Przykładem tych drugich mogą być miasta polskie, które realizując wskazania obowiązujących regulacji prawnych (np. Ustawy o planowaniu i zagospodarowaniu przestrzennym) wywołują to hasło w opracowywanych strategiach rozwoju.

Zmiany klimatyczne obserwowane we wszystkich częściach naszego globu dowodzą, że proces eksploatacji Ziemi musi zostać zahamowany, tak aby realizowany był, jak głosi definicja, rozwój społeczno-gospodarczy, w którym następuje proces integrowania działań politycznych, gospodarczych i społecznych, z zachowaniem równowagi przyrodniczej oraz trwałości podstawowych procesów przyrodniczych, w celu zagwarantowania możliwości zaspokajania podstawowych potrzeb poszczególnych społeczności lub obywateli zarówno współczesnego pokolenia, jak i przysztych pokoleńn ${ }^{3}$. 
Zrównoważony rozwój miast jest oparty na systemie planowania przestrzennego oraz projektowania urbanistycznego i architektonicznego, które warunkują kształt i zasady przekształceń przestrzeni miejskiej. Jest to proces obejmujący wszystkie zagadnienia życia miejskiego jako współzależną relację pomiędzy gospodarką, społeczeństwem i środowiskiem w zakresie m.in. budownictwa, infrastruktury technicznej w tym transportu miejskiego, gospodarki odpadami itd.

Współczesne przemiany struktury miejskiej opierają się dążeniach do koncentracji zabudowy zgodnie z ideą miasta zwartego oraz zapobieganiu procesom rozproszenia miast. Celem jest również poprawa jakości życia mieszkańców miast poprzez poprawę jakości przestrzeni miejskiej a przede wszystkim przestrzeni publicznej. Współczesny człowiek, wciągnięty w przestrzeń wirtualnego świata jest często wyzuty z prawidłowo funkcjonujących relacji społecznych, które są mu potrzebne dla poczucia szczęścia i satysfakcji ${ }^{4}$. To prowadzi do transformacji miast zaprojektowanych z myślą o ludziach i ich potrzebach - nawet jeśli zakres tych potrzeb musi zostać w wielu przypadkach zweryfikowany aby wirze pogoni za sukcesem zawodowym czy finansowych zdać sobie sprawę z tego czy aby te dokonania nie są opłacone wysoką ceną bierności emocjonalnej.

Transformacja przestrzeni miasta zrównoważonego to przede wszystkim poprawa jakości przestrzeni publicznych oraz większy udział zieleni w krajobrazie miasta w postaci m.in. nowych parków i skwerów czy też różnych form zazieleniania ulic miasta. Transformacja ta jest również zauważalna poprzez ograniczenie ruchu samochodowego, szczególnie w centralnych częściach miast. Ograniczenie to odbywa się na rzecz transportu zbiorowego (tramwajów, autobusów) i dużego udziału ruchu rowerowego (ścieżki rowerowe). Jest to zmiana bardziej pośrednia dotyczy bowiem bardziej form użytkowania przestrzeni miast a nie trwałych elementów zagospodarowania. Jej wpływ jednak na kształtowanie przestrzeni miejskiej jest znaczący gdyż zmienia sposób użytkowania przestrzeni a przez to sposób jej projektowania - na przykład redukcja miejsc parkingowych.

\section{Podsumowanie}

Miasta współczesne to miasta dynamiczne a temat transformacji przestrzeni miejskich to bardzo rozległe i złożone zagadnienie. Zmieniają się przestrzenie miast bowiem zmieniają się ludzie i dlatego proces zmian dotyczy zarówno form przestrzennych jak również sposobów użytkowania przestrzeni miejskich. Nowy styl życia mieszkańców związany jest jednocześnie z pracą zawodową i sposobem spędzania wolnego czasu.

Analiza uwarunkowań rozwoju i występujących w poszczególnych miastach zależności jest istotna aby zdefiniować kierunek ich przyszłego rozwoju i podjąć próbę wprowadzenia narzędzi mających na celu minimalizację już istniejących negatywnych procesów przemian.

Miasta się zmieniają i tych procesów transformacji nie da się zatrzymać. Nie taki jest zresztą cel. Wymienione w artykule transformacje przestrzeni miejskich w wielu przypadkach występują równolegle - tak jak na przykład globalny Nowy Jork i jego strategia zrównoważonego rozwoju czy wyludniająca się łódź i podjęte procesy rewitalizacyjne. Każde miasto jest inne bo inne są uwarunkowania jego rozwoju. Wnioskiem przedstawionej analizy jest to, że mimo iż aspekty przestrzenne wydają się mieć mniejszą wagę w obliczu aspektów gospodarczych czy społecznych (i trudno się z tą tezą nie zgodzić), to jednak ich siła wzajemnego oddziaływania jest bardzo duża i nie można jej ignorować. Jakość przestrzeni miejskiej

\footnotetext{
4 Charles Montgomery podejmuje ten temat w swej książce „Miasto szczęśliwe”.
} 
jest bowiem ważnym czynnikiem mającym wpływ na budowanie pozytywnego obrazu miasta związanego z poziomem atrakcyjności inwestycyjnej czy osiedleńczej.

\title{
Literatura
}

[1] Harańczyk A. (red.), Uwarunkowania i konsekwencje procesu kurczenia się miast, Wydawnictwo CeDeWu Sp. z o.o., Warszawa 2015.

[2] Jałowiecki B., Szczepański M.S., Miasto i przestrzeń w perspektywie socjologicznej. Wydawnictwo Naukowe SCHOLAR, Warszawa 2010.

[3] Jopek D., Przestrzenne aspekty procesu kurczenia się miast [w:] Harańczyk A.(red.), Uwarunkowania i konsekwencje procesu kurczenia się miast, Wydawnictwo CeDeWu Sp. z o.o., Warszawa 2015.

[4] Lorens P., Wspótczesne przemiany struktury miast i obszarów metropolitalnych, Konferencja PW Miasto Idealne - Miasto Zrównoważone, Planowanie przestrzenne terenów zurbanizowanych i jego wpływ na ograniczenie skutków zmian klimatu, Warszawa 2014

[5] Sassen S., The Global City, Princeton, N.J.: Princeton University Press 2001.

[6] Wiśniewska D., Zarządzanie rozwojem przestrzennym miast w kontekście glokalizacji [w:] Zarządzanie rozwojem przestrzennym miast, P. Lorens, J. Martyniuk-Pęczek (red.), Wydawnictwo Urbanista, Gdańsk, 2010.

[7] Zuziak Z., Strategie rewitalizacji przestrzeni śródmiejskiej, Politechnika Krakowska, Kraków 1998.

\section{The processes of transformation of contemporary cities based on selected examples}

\section{Dorota Jopek}

Cracow University of Economics, jopekd@uek.krakow.pl

\begin{abstract}
Contemporary cities are influenced by dynamic spatial transformation related to demographic, social and economic changes. As a result of these factors, the development challenges of urban centers may be extremely different. Some of the cities are subject to a process of depopulation associated with both negative demographic trends and an increase of unemployment and the lack of jobs for young people. The second part of the cities are the centers with better growth potential derived mostly from their historical role in the development of the entire country carried out at various levels. This variety of growth factors is created by the beneficial impact of the institutions of scientific, cultural and private economic sector. The attractiveness of these cities due to an increased and diversified offer on the labor market and better living conditions for their inhabitants is carried out among others by the availability of high-quality public space.

In studies of the process of transformation of cities, spatial aspects seem to be less important in the combination of economic, demographic and social aspect. Although its interdependencies evident, however, spatial changes are mostly influenced by all of above aspects. Analysis of planning documents and urban development strategy shows that most of the contemporary cities target on the improvement of the quality of life of their residents and the implementation of the principles of sustainable development. In this paper, the author attempts to study the processes of transformation taking place in contemporary cities.
\end{abstract}

Keywords: city, globalization, revitalization, depopulation. 